\title{
Difference of Calcium Levels in Infants with Low Birth Weight
}

\author{
Sandi Nugraha, Harsono Salimo, Dwi Hidayah
}

Department of Pediatrics, Universitas Sebelas Maret/ Dr. Moewardi Hospital, Surakarta

\section{ABSTRACT}

Background: Hypocalcemia is a condition that can cause serious disorders, especially in newborns. The occurrence of hypocalcemia is an event that often occurs in babies born that can be caused due to late parathyroid hormone function in calcium metabolism in the baby's body. Hypocalcemia is often associated with hypotension and disorders of the heart rhythm, symptoms that are often seen are apnea, tachycardia, lethargy, vomiting, and gastrointestinal disorders. This study aimed to analyze differences in calcium level between low birth weight infants.

Subjects and Method: A cross sectional study was conducted at Dr Moewardi Hospital, Surakarta, Central Java, from December 2016 to April 2017. A sample of $158 \mathrm{LBW}$ children was selected using consecutive sampling. The dependent variable is a decrease in calcium levels. The independent variable is low birth weight babies. Data collected by medical records. Data were analyzed using multiple logistic regression.

Results: Calcium level $\geq 1.13 \mathrm{mmol} / \mathrm{L}(\mathrm{OR}=$ $0.30 ; 95 \% \mathrm{CI}=0.15$ to $0.57 ; \mathrm{p}<0.001)$, no seizures $(\mathrm{OR}=0.20 ; 95 \% \mathrm{CI}=0.06$ to $0.64 ; \mathrm{p}=$ $0.004)$, and QoTC (OR=0.20; 95\% CI=0.07 to $0.572 ; \mathrm{p}=0.003$ ) decreased the risk of low birth weight.

Conclusion: Calcium level $\geq 1.13$, no seizures, and QoTC decrease the risk of low birth weight.

Keywords: low birth weight, hypocalcemia

\section{Correspondence:}

Sandi Nugraha. Department of Pediatrics, Universitas Sebelas Maret/ Dr. Moewardi Hospital, Surakarta. Phone/Fax.0271-633348. Email:sssandinugraha@gmail.com

Cite this as:

Nugraha S, Salimo H, Hidayah D (2020). Difference of Calcium Levels in Infants with Low Birth Weight. Indones J Med. 05(02): 131-136. https://doi.org/10.26911/theijmed.2020.05.02.06

(c) (i) (2) Indonesian Journal of Medicine is licensed under a Creative Commons

(c) $\mathrm{EY}$ NC SA Attribution-NonCommercial-ShareAlike 4.0 International License.

\section{BACKGROUND}

The problem is more common in infants and infants with low birth weight (LBW). Problems that often occur are metabolic disorders, one of which is hypocalcemia (Jain et al., 2008; Ronald et al., 2011).

Hypocalcemia is a condition that can cause serious disorders, especially in newborns. The occurrence of hypocalcemia is an event that often occurs in babies born that can be caused due to late parathyroid hormone function in calcium metabolism in the baby's body. Baby's calcium during the womb is actively transferred from the mother's circulation to the fetus's circulation through a transplacental calcium pump that is regulated by the hormone parathyroid-related pep- tide (PTHrP). The majority of fetal calcium transport is increased in the third trimester, this process results in higher calcium concentrations in the fetus compared to the mother which causes hypercalcemia in the fetus, with total calcium concentrations ranging from 2.5 to $2.75 \mathrm{mmol} / \mathrm{L}$ and ionized calcium around $1.5 \mathrm{mmol} / \mathrm{L}$ that can be measured in umbilical cord blood in term babies (Series I et al., 2005). Hypocalcemia can occur in premature babies, mothers with diabetes, and babies who have asphyxia. Premature infants, hypocalcemia is associated with the cessation of active calcium transport during pregnancy and in asphyxia infants can be caused by renal insufficiency, metabolic acidosis, and secretion of parathyroid hormone (PTH) 
when the baby is born thereby reducing plasma calcium levels.

Hypocalcemia is often associated with hypotension and disorders of the heart rhythm, the symptoms that are often seen are apnu, tachycardia, lethargy, vomiting, and gastrointestinal disorders (Brownet al., 20oo; Zhou et al., 2009). In newborns it is said hypocalcemia if the total calcium level is below $2.00 \mathrm{mmol} / \mathrm{L}$ in term infants, and under $1.80 \mathrm{mmol} / \mathrm{L}$ in preterm infants. Mild hypocalcemia if the value of calcium 2.00$2.12 \mathrm{mmol} / \mathrm{L}$ can be seen without symptoms, moderate hypocalcemia if the value of total calcium levels is 1.90-2.00 mmol/L, and neuromuscular symptoms can be seen in severe hypocalcemia with calcium levels <1.90 mmol/L (Mimoumi et al., 1994; Aggrawal et al., 2008).

\section{Study Design}

This was a cross-sectional study conducted at Dr. Moewardi hospital, Surakarta.

\section{Population dan Sample}

The study population was infants with birth weight <2,500 grams. A sample of $158 \mathrm{LBW}$ infants was selected by consecutive sampling.

\section{Study Variables}

The dependent variable of this study birth weight. The independent variables were calcium level, gender, calcium supplement, convulsion, and QoTC.

\section{Operational Definition of Variables} Low birth weight was infants born with birth weight $<2,500$ grams regardless of gestation. Birth weight is the weight of a baby weighed a maximum of 24 hours after birth (Damanik, 2008).

Small for gestational age (SGA) was infants born with birth weights between the 10th and 9oth percentiles according to the weight relationship/gestational age. The measurement scale is using a nominal scale
Intra-uterine growth restriction was infants born with birth weight $<1$ oth percentile for estimated fetal weight (EFW) according to the Lubchenco chart. Infants with IUGR will be assessed based on birth weight which is then plotted to the Lubchenco body weight/gestational age chart (Damanik, 2014; Gomella, 2013). The measurement scale was continous.

Hypocalcemia was defined by various restrictions, such as calcium levels less than $1.13 \mathrm{mmol} / \mathrm{L}$. Measurement of calcium levels was carried out using the ion-selective electrode (ISE) method. The samples used are blood and tubes without additional substances. Storage time until inspection is recommended not more than 30 minutes, with a temperature of $15-30^{\circ}$ Celsius. The measurement tool used is the AVL ROCHE 9180 engine.

The QT interval (QoTC) was a measurement made on an electrocardiogram used to assess some of the electrical properties of the heart.

\section{Study Instruments}

Data collected from medical records and questionnaires.

\section{Data Analysis}

Univariate analysis describes data in $\mathrm{n}$ and\% values. The relationship of each independent variable to the dependent variable was analyzed using Chi square.

\section{Research Ethic}

This study was approved by the Board of Health Research Ethics Commission Dr. Moewardi hospital/Sebelas Maret University School of Medicine Number: 842/X/ HREC / 2016.

\section{RESULTS}

\section{A. Univariate analysis}

Overall infants had an average birth weight of 1,970 grams $($ Mean $=1,970.79 ; \mathrm{SD}=354)$. Of 158 babies, there were 81 (51.26\%) IUGR infants and 77 (48.73\%) were SGA infants. 
Nugraha et al./ Difference of calcium levels in infants with low birth weight

Table 1. Sample Frequency Distribution

\begin{tabular}{lc}
\hline Variable & $\mathbf{N}$ \\
\hline Gender: & \\
- Male & $83(52.53 \%)$ \\
- Female & $75(47.47 \%)$ \\
Pregnancy Age: & \\
- LBW & $83(52.53 \%)$ \\
- VLBW & $50(31.65 \%)$ \\
- ELBW & $25(15.82 \%)$ \\
Calcium Level: & \\
- $\geq 1.13$ mmol/L & $85(53.80 \%)$ \\
- <1.13 mmol/L & $73(46.20 \%)$ \\
Calcium Supplement: & \\
- Yes & $45(28.48 \%)$ \\
- No & $113(71.52 \%)$ \\
Nutrition & \\
- Formula & $65(41.14 \%)$ \\
- Breastmilk + human milk fortifier (HMF) & $21(13.29 \%)$ \\
- Exclusive breastfeeding & $72(45.57 \%)$ \\
Convulsions & \\
- Yes & $61(38.61 \%)$ \\
- No $>$ QoTC & $97(61.39 \%)$ \\
- Yes & \\
- No & $82(51.89 \%)$ \\
Mortality: & $76(48.11 \%)$ \\
- Alive & \\
- Dead & $124(78.48 \%)$ \\
\hline
\end{tabular}

Table 2. Relationships of calcium levels, sex, calcium supplements, nutrition, QoTC seizures, mortality, and infant birth weight

\begin{tabular}{|c|c|c|c|c|c|c|}
\hline \multirow{2}{*}{ Variable } & \multicolumn{2}{|c|}{ SGA } & \multicolumn{2}{|c|}{ IUGR } & \multirow{2}{*}{$\mathbf{O R}$} & \multirow{2}{*}{$\mathbf{p}$} \\
\hline & $\mathbf{n}$ & $\%$ & $\mathbf{n}$ & $\%$ & & \\
\hline \multicolumn{7}{|c|}{ Calcium Level } \\
\hline$<1.13$ & 24 & 32.9 & 49 & 67.1 & \multirow[t]{3}{*}{0.30} & \multirow[t]{2}{*}{$<0.001$} \\
\hline$\geq 1.13$ & 53 & 62.4 & 32 & 37.6 & & \\
\hline \multicolumn{6}{|l|}{ Gender } & \\
\hline Male & 41 & 49.4 & 42 & 50.6 & \multirow[t]{2}{*}{1.06} & \multirow[t]{2}{*}{0.431} \\
\hline Female & 36 & 48.0 & 39 & 52.0 & & \\
\hline \multicolumn{7}{|c|}{ Calcium } \\
\hline \multicolumn{7}{|c|}{ Supplement } \\
\hline Yes & 11 & 45.83 & 14 & 28.57 & \multirow[t]{3}{*}{2.12} & \multirow[t]{2}{*}{0.144} \\
\hline No & 13 & 54.17 & 35 & 71.43 & & \\
\hline \multicolumn{6}{|c|}{ Convulsion } & \\
\hline Yes & 14 & 58.33 & 43 & 87.75 & \multirow[t]{3}{*}{0.20} & \multirow[t]{2}{*}{0.004} \\
\hline No & 10 & 41.67 & 6 & 12.24 & & \\
\hline \multicolumn{6}{|l|}{ QoTC } & \\
\hline Yes & 8 & 33.33 & 35 & 71.43 & \multirow[t]{2}{*}{0.20} & \multirow[t]{2}{*}{0.003} \\
\hline No & 16 & 66.67 & 14 & 28.57 & & \\
\hline
\end{tabular}

The average body weight of IUGR infants was 2,044 grams $(\mathrm{Mean}=2044.67 ; \mathrm{SD}=251)$ and the average weight of SGA infants was 1,896 grams $($ Mean=1,896.76; SD = 167). Average 
Nugraha et al./ Difference of calcium levels in infants with low birth weight

calcium levels (Mean $=1.07 ; \mathrm{SD}=0.09)$, with 73 infants (46.20\%) experiencing hypocalcemia with serum calcium levels $<1.13 \mathrm{mmol} / \mathrm{L}$ and 85 infants (53.79\%) with normal calcium levels $\geq 1.13 \mathrm{mmol} / \mathrm{L}$.

\section{B. The result of bivariate analysis}

Table 2 shows the relationship of calcium levels, sex, calcium supplements, nutrition, QoTC seizures, mortality, and infant birth weight. Table 2 shows that calcium levels $\geq 1.13$ (OR=0.30; $\mathrm{p}<0.001$ ), no seizures (OR= $0.20 ; \mathrm{p}=0.004)$, and no QT interval $(\mathrm{OR}=$ $0.20 ; p=0.003$ ) reduce the risk of birth weight low according to gestational age.

Table 2 showed that female sex $(\mathrm{OR}=$ 1.06; $\mathrm{p}=0.431)$ and not getting Ca supplements $(\mathrm{OR}=2.12 ; \mathrm{p}=0.144)$ increases the risk of low birth weight small gestational age.

\section{DISCUSSION}

Low calcium levels in IUGR infants are caused by malfunctioning of organs optimally. When the baby is born, active calcium transport during pregnancy will be stopped while in infants with low birth weight often there is renal insufficiency, metabolic acidosis, and secretion of parathyroid hormone (PTH) is less at the time of the baby which can cause a decrease in plasma calcium levels (Horne et al., 2004; Zhou et al., 2009). But in infants with LBW, the amount of glomerulus is still lacking, so that the postnatal renal flow increases, and the Glomerolus Filtration Rate (LFG) decreases. In addition, gastrointestinal tract maturation in LBW infants is also hampered so that calcium absorption through nutrient supply is also less than optimal (Elizabeth et al., 2007; Kamilah et al., 2008).

The newborn babies with SGA suffer from various metabolic problems such as metabolic acidosis, obvious hypoglycemia, hypocalcaemia (Mazumder et al., 2012). A study by Honarpisheh (2003) reported that about $25 \%$ of low birth weight infants developed early hypocalcemia. Inadequate die- tary intake of calcium may lead to a decrease in serum calcium levels (Peacock, 2010; Kant et al., 2019). Some complications of pregnancy may be associated with lower serum calcium levels e.g. pre-eclampsia during pregnancy, low birth weight, preterm delivery, and neonatal death (Sabour et al., 2006; Hofmeyr et al., 2014).

Chi square test results showed significantly different results in seizure variables and prolongation of the QT interval between hypocalcemia in infants with SGA and IUGR. The results of this study were followed by an analysis looking for Odd Ratio and significant results were squeezed into seizure variables and lengthening the QT interval. The seizure variables were obtained $(\mathrm{OR}=0.20 ; 95 \% \mathrm{CI}=$ 0.06 to $0.64 ; \mathrm{p}=0.004$ ) which showed that the incidence of hypocalcemia in infants with SGA was 5.12 times less likely to cause seizures compared to hypocalcemia in IUGR infants. Seizures in neonates arise as a consequence of neural injury, resulting from hypoxia, ischemia, or metabolic disturbances such as hypoglycemia or hypocalcemia (Davis et al., 2010).

Prolongation of QT interval $(\mathrm{OR}=0.2 \mathrm{O}$; 95\% $\mathrm{CI}=0.07$ to $0.57 ; \mathrm{p}=0.003$ ) shows that the incidence of hypocalcemia in infants with SMK has a 5 times lower probability of causing prolongation of QT intervals compared with hypocalcemia in IUGR infants. QT (c) and QT (d) in young adults previously born preterm with an ELBW were correlated with gestational age and birth weight (Bassareo et al., 2011).

\section{AUTHOR CONTRIBUTION}

Sandi Nugraha did the study and wrote the manuscript. Harsono Salimo and Dwi Hidayah wrote the manuscript and suggested the discussion materials.

\section{CONFLICT OF INTEREST}

There is no conflict of interest in this study. 
Nugraha et al./ Difference of calcium levels in infants with low birth weight

\section{FUNDING AND SPONSORSHIP}

This study is self-funded.

\section{ACKNOWLEDGEIMENT}

The author would like to thank all those who have helped this research, namely the patients and parents of the subjects of the study, the Head of Room and Nurse of the NICU and HCU Neonates, Clinical Pathology Laboratory of Dr. Moewardi Hospital Surakarta, and all those who contributed in this study.

\section{REFERENCE}

American Academy of Pediatrics, Committee on Fetus and Newborn, and the American college of Obstetricians and Gynecologists, Committee on Obstetrics. 1988. Maternal Fetal Medicine: Guidelines for Perinatal Care. Elk Grove Village, III. American Academy of Pediatrics.

Bassareo PP, Fanos V, Puddu M, Cadeddu C, Balzarini M, Mercuro G (2011).Significant QT interval prolongation and long QT in young adult ex-preterm newborns with extremely low birth weight. J Matern Fetal Neonatal Med.24(9):1115-8. doi: 10.3109/14767058.2010.543600.

Damanik SM. 2008. Klasifikasi Bayi Menurut Berat Lahir dan Masa Gestasi (Classification of babies according to birth weight and gestation period). Hlm 11-2. Dalam: Kosim MS, Yunanto A, Dewi R, Sarosa GI, Usman A, penyunting. Buku Ajar Neonatologi.Jakarta: IDAI.

Davis AS, Hintz SR, Van Meurs KP, Li L, Das A, Stoll BJ, Walsh MC, et al. (2010). Seizures in extremely low birth weight infants are associated with adverse outcome. J Pediatr. 157(5): 720-725.e2. doi: 10.1016/j.jpeds.2010.04.065

Elizabeth KE, Krishnan V, Zachariah P (2007). Auxologic, Biochemical and Clinic- al (ABC) Profile of Low Birth Weight Babies-A 2-year Prospective Study. Journal of Tropical Pediatrics, 53(6): 374-382.https://doi.org/10.1093/tropej/fmmo48

Gomella TL (2013). Assessment of Gestational Age. Dalam: Cuningham FG, Mac Donald PC, Gant NF, penyunting. Neonatology; Management, Procedures, On Call Problem, Diseases, and Progress. Edisi 15. New York: Mc Graw Hill.

Hofmeyr GJ, Lawrie TA, Atallah AN, Duley L, Torloni MR (2014). Calcium supplementation during pregnancy for preventinghypertensive disorders and related problems. CochraneDatabase Syst Rev. (6):CDo01059.https://doi.org/10.1002/14651858.CDoo1059.pub4

Honarpisheh A (2003). Frequency of hypocalcemia in low birth weight infants at hospitals inKashan in 1997. Med J of the Islamic Republic of Iran. 17(1): 4750. http://mjiri.iums.ac.ir/article-1-722-en.pdf

Horne H S. 2004. Electrolyte Balance. Dalam: Swearingen P.L.Penyunting. Fluid, Electrolite and Acid-Base Balance. Edisi ke-5. St Louis, Missouri: Mosby-year book Inc.

Jain A, Agarwal R, Sankar MJ, Deorari A, Paul VK (2008). Hypocalcemia in the Newborn. Indian J Pediatr.77(10):11238. doi: 10.1007/s12098-010-0176-o

Kamilah BR. 2008. Gangguan Cairan dan Elektrolit. Dalam: Kosim MS, Yunanto A, Dewi R, Sarosa GI, Usman A, penyunting. Buku Ajar Neonatologi; Jakarta: IDAI.

Kant S, Haldar P, Gupta A, Lohiya A (2019). Serum calcium level among pregnant women and its associationwith preeclampsia and delivery outcomes: A cross-sectional study from North India. Nepal J Epidemiol.9(4): 795-803.doi: 10.3126/nje.v9i4.23150 
Nugraha et al./ Difference of calcium levels in infants with low birth weight

Mazumder MW, Begum N, Mannan MA (2012). Study of blood glucose and serum calcium level in small forgestational age babies. J Shaheed Suhrawardy Med Coll, 4(2):50-52.

Mimouni F, Tsang. 1994. Neonatal hypocalcemia:To treat or not to treat?. J Am Coll Nutr.13(5):408-15.

Peacock M (201). Calcium metabolism in health and disease. Clin J Am SocNephrol. 5(1): S23-30. https://doi.org/10.2215/CJN.05910809

Ronald S, Bloom M, Cropley C (2011). Neonatal Resuscitation. Dalam : Kattwinkel. J. Penyunting. Textbook Of Neo- natal Resuscitation. Edisi ke-6. Philadelphia: American academy of pediatric.

Sabour H, Hossein-Nezhad A, Maghbooli Z, Madani F, MirE, Larijani B (2006). Relationship between pregnancy outcomes andmaternal vitamin D and calcium intake: A cross-sectional study. Gynecol Endocrinol. 22(10):585-9. Https://doi.org/10.1080/09513590601005409

Zhou P, Adam (2009). Hypocalcemia in infants and children. Pediatr Rev. 30(5): 190-2. doi: 10.1542/pir.30-5-190. 